Mario Sánchez Latorre

\title{
El problema del humanismo en Ortega y Gasset
}

"Si el hombre debe cncontrar de nuevo el camino hacia la proximidad del ser, entonces tiene primero que aprender a existir en lo innominado".-Heidegger, "Carta sobre el humanismo".

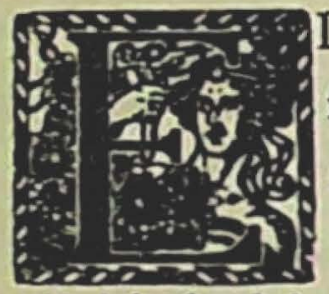

L humanismo subyace en el conjunto de indagaciones filosóficas de Ortega. Tal vez es el dramático nervio de su vida toda, el aleteo incesante en su búsqueda de la realidad que sustenta al asombro. Sondear la multiplicidad del fenómeno que designa la palabra humanismo, rastrear el curso de su mirada en este problema y comprender las señales que de él obtuvo es la tarea un poco atrevida-que se propone este escrito.

Se puede obtener un concepto del humanismo del siglo XVIII o XV e incluso valorarlo. Valorar es remitir el concepto a su origen en comparación de autenticidad, pero sobre el humanismo como algo real, sólo se pueden dar ciertas señales en forma de proposiciones. La proposición no abstrae sino que hace referencia. El concepto aprisiona la aspiración de algo, pero no da caza a lo que surte la aspiración.

Lo humano es el rasgo indisoluble que pertenece y muestra al 
hombre preocupado en la meditación de su destino y en este meditar construye su humanidad. Tarea en que se realiza como tal.

El humanismo es todo pensar al hombre en su destino. Encierra la posibilidad de edificar sistemas, pero no puede ser un sistema, porque esta posibilidad del hombre es pensar su ser viviente.

El humanismo es un modo de ver y, más profundamente, de ser. Es una permanente pregunta a lo real que escucha la respuesta que éste le da. No venera, sino que ama. No interpreta, sino que describe y señala en vez de enjuiciar. Su amor es hacia la vida y los objetos que la aspiran. No los admira, sino que vibra con su temblor.

Este fué el humanismo de la antigüedad. Existió sin nombre y fundamentó sistemas. El del siglo XV adoró dioses que habían agotado su sentido para ser amados. Vivió en academias y recibió designación.

Pues bien, ¿cuál fué el humanismo de Ortega? Para contestar esta interrogante tenemos que remitirnos a su actitud y luego al resultado de ella.

Frente a Ortega se ha producido el fenómeno del desconcierto y más que nada de la incomprensión. Creo que una de las responsabilidades mayores entregadas por él, es la de comenzar a entenderlo.

Una somera ojeada en los juicios e impresiones formados en la tarea de entender a cualquier ser humano en tránsito por el mundo, muestra un resultado disparejo. La posibilidad del equívoco evidencia su desmesurado rostro. Los juicios desenvuelven una vida impersonal, desprovista de raíces seguras. Las impresiones ofrecen una desvinculación con su origen y esta sonambulesca constelación se erige en el contenido real de las interpretaciones ulteriores.

No obstante intervenir en este proceso elementos simples y determinados, la función de entender es opaca y exhibe una misérrima condición.

El desarrollo objetivo de entender a un pensador brinda la misma similitud que el de este ser humano, con una complicación: el pensador comunica su pensamiento en un ámbito mucho más amplio que el de un hombre cualquiera, con el agravante de que esta 
comunicación supone un peculiar silencio: el de los que callan para escuchar a alguien preocupado de algo.

Silencio de oídos y almas tensas, no de espacio, sino de otros hombres.

Escuchar implica un callarse, un aprendizaje que emerge de la tradición. Una actitud que se funda en la posibilidad de recibir el contenido genuino de lo que se escucha. Actitud en peligro de desvirtuarse por la veneración, riesgo constante y aún mayor que el de no comprender, pues el primero franquea el fanatismo que es un reiterar monocorde y en acción de lo ya dicho.

Recurrimos a lo pensado por un filósofo para comprender la realidad sometida a su meditación y no para vagar por los resultados de su pensamiento cual espectros en un mundo de tinieblas.

Entender no es únicamente captar lo pensado, sino esencialmente comprender lo que hace posible pensar.

En este sentido la menos orteguiana de las posiciones es la veneración de Ortega. Admiración de incontables adjetivos y huecos cubiertos con aletazos de exclamaciones.

Entender a Ortega no es únicamente comprender su pensamiento $\mathrm{y}$ su método, sino fundamentalmente, ubicar nuestra posibilidad de meditar en el fenómeno real que él pensó.

¿Y cuál fué la actitud de Ortega?

La actitud es un suceso en cuya contextura espiritual converge energía humana. Contextura en vigilia constante. Su génesis es la vocación y la misión es su ejercicio. A través de ella el hombre expresa libremente su manera de ser. Es el lugar donde lo conocemos, el perdido escondite en que le damos caza.

Este es Ortega en su mundo: vigilante, sin fanatismo, expresión libre, fiel a su vocación, interrogador incansable de hombres y cosas. Auténtico humanista.

Un filósofo es un hombre que piensa. Tal vez parece una afirmación perogrullesca, pero su misma sencillez la hace actuar en la epidermis de nuestra conciencia y por ende relegarla en el regazo 
del olvido. Porque no sólo no nos debemos olvidar de que piensa, sino también, de que es un hombre.

El procedimiento de pensar se efectúa por sorpresivas capturas. La destreza es su elemento esencial, pero es un arma obtenida en pruebas innúmeras, el golpe en el hombro al que el señor feudal consagraba caballero.

Ahora se puede desentrañar la segunda frase de este escrito: búsqueda de la realidad que sustenta al asombro.

El asombro es cuestionar, suspender el juicio. Es previo a la pregunta. El preguntar eleva su interrogación en el radicarse del asombro y la fórmula a lo que lo promueve. Asombro es una situación sorpresiva del hombre y por medio del mismo se descubre en esta actitud que es "un saber a qué atenerse".

"Saber" es el resultado de un propósito que satisface una inquietud esencial. "A qué" es la dirección de este resultado, el sendero por donde se muestra. "Atener-se" es guardar, tener algo, y "se" quien lo guarda. El contenido del "atenerse" es el "saber".

El sentido ontológico de la proposición "saber a qué atenerse" es el siguiente: El hombre es guardián de su contenido, tiene en su mano la satisfacción de su inquietud.

Santiago, 6 de febrero de 1956. 